Volume 5 Number 1 April 2019 page 9-19

p-ISSN:2460-1497 and e-ISSN: 2477-3840

DOI: https://doi.org/10.26858/est.v5i1.7848

\title{
Students' Higher Order Thinking Skills in Environmental Learning: Develop Assessment Based on Green Consumerism
}

\author{
Ilmi Zajuli Ichsan', Diana Vivanti Sigit ${ }^{2}$, Mieke Miarsyah ${ }^{3}$ \\ ${ }^{1}$ Biology Education Program, Universitas Negeri Jakarta, Indonesia \\ Email: ilmizajuli95@gmail.com \\ ${ }^{2}$ Biology Education Program, Universitas Negeri Jakarta, Indonesia \\ Email: dianav@unj.ac.id \\ ${ }^{3}$ Biology Education Program, Universitas Negeri Jakarta, Indonesia \\ Email: mmiarsyah@unj.ac.id
}

(Received: January-2019; Reviewed: March-2019; Accepted: April-2019; Published: April-2019)

\begin{abstract}
21st-century learning emphasizes several important abilities, one of which is the ability of Higher Order Thinking Skills (HOTS). This ability can be possessed by students by familiarizing students with HOTS-based questions. The purpose of this study was to develop HOTS-based questions on environmental learning based on green consumerism and measure HOTS of students. The research method used is research and development using Borg and Gall Model. The study was conducted in November 2018 at State Junior High School 1 South Tambun. The validation results showed that the assessment on green consumerism-based environmental learning developed has a very valid category according to the experts, and is valid and reliable after measurement. This is because the questions developed are relevant to the current environmental conditions. The results of HOTS male students 44.98 and female students 46.61. The average score of Male and Female 45.79 are still relatively low and need to be improved. The conclusion is that the questions developed have a valid, reliable and appropriate category of use in the process of learning science in junior high school.
\end{abstract}

Keywords: HOTS, Assessment, Green Consumerism.

\section{INTRODUCTION}

Environmental learning in the 21 st century carried out in the classroom began to focus on improving Higher Order Thinking Skills (HOTS). Good learning certainly does not only lead students to memorize various terms and definitions of various environmental concepts. More than that, environmental learning must be able to stimulate students 'analytical power and foster students' critical power. This ability is very important in the development of students in dealing with various problems and it is hoped that students can provide solutions to these problems(Sharif \& Cho, 2015; Talmi, Hazzan, \& Katz, 2018; Wall, 2015; Weninger, 2018).

The problem that arises is certainly the problems related to the environment such as air pollution, the amount of plastic waste, forest destruction and so on. All these environmental problems really require HOTS students to solve them. The role of HOTS is very much needed in solving these problems because it requires sharp analytical power. Students are one of the parties who can contribute to solving these problems by having good analytical skills (Çankaya \& Dag, 2017; Owusu-Agyeman, Larbi-Siaw, Brenya, \& 
Anyidoho, 2017; Xia, 2017).

In general, environmental problems such as air pollution, energy use, purchasing green products can be summarized into one concept called green consumerism. Briefly, Green Consumerism (GC) can be interpreted as an understanding of a consumer to buy and consume various products for his life needs based on the environmentally friendly level of the product. Someone who has a high GC will usually prefer environmentally friendly products even though he has to pay more $(\mathrm{Gu}$, Chhajed, Petruzzi, \& Yalabik, 2015; Han \& Yoon, 2015; Lekakos, Vlachos, \& Koritos, 2014; Matthes \& Wonneberger, 2014).

The link between HOTS and GC is where a student who has a high HOTS can do analysis and evaluation of the use of various green products in their daily lives. In addition, high HOTS students are expected to make students more critical in buying and consuming various products on the market. This certainly becomes a separate focus in learning. In addition to analyzing and criticizing, students with high HOTS can also design a project/product that is environmentally friendly in accordance with GC principles (Gu et al., 2015; Vidergor \& KrupnikGottlieb, 2015; Vijayaratnam, 2012).

The constraints faced by teachers in environmental learning are one of the few problems that have HOTS characteristics. This causes environmental learning to be increasingly difficult to measure from the HOTS aspect. Meanwhile, the demands of the 21st century require students to have high HOTS. Based on these problems there is a gap analysis where the teacher's need for HOTS assessment is not available, while the assessment is very necessary. This has made development research to develop HOTS assessments necessary, especially those containing GC concepts. The purpose of this study was to develop HOTSbased questions on environmental learning based on green consumerism and measure HOTS of students.

\section{METHOD}

This study used research and development methods with the development model of Borg and Gall. The research was conducted in November 2018 at Tambun Selatan 1 Junior High School, Bekasi, Indonesia. This school was chosen because it applied environment-based learning to its curriculum. The development carried out consisted of several adjusted stages, namely (1)conducting a needs analysis (2) conducting an assessment design (3) carrying out an assessment development (4) conducting expert validation (5) conducting a limited trial in the class (Gall, Gall, \& Borg, 2003).

Needs analysis: carried out by conducting observations and conducting interviews, the result is that learning devices need to be developed in this case a better assessment is related to HOTS.

Design assessment: carried out for a week. The questions that are designed include HOTS capabilities, namely C4 (analyzing), C5 (evaluating), and C6 (Creating) which are aspects of the HOTS that have been updated (Anderson et al., 2001).

Develop Assessment: based on the basic competencies that have been established, namely $\mathrm{KD} 3.8$ Analyze the occurrence of environmental pollution and its impact on the ecosystem.

Expert validation: Experts involved consist of lectures, a student at a master education degree and teacher. The validation criteria used are according to Ratumanan \& Laurens (2006) which can be seen in table 1.

Limited trial: to students. The sample was selected by simple random sampling, obtained by 55 male students and 55 female students in Junior High School 1 South Tambun. The trial was conducted in November 2018. Analysis of the data used was to conduct Validity analysis using Pearson Product Moment (Pearson Correlation) to determine validity, then performed a reliability test with split half (spearman brown) technique. Determination of the instrument is reliable or not based on Ratumanan \& Laurens (2006) seen in table 2. Additional analysis was carried out by comparing HOTS scores of male and female students through the t-test. 
Table 1. Categories of assessment Validity by expert

\begin{tabular}{ll}
\hline Interval Category & Criteria \\
\hline $\mathbf{3 , 2 5}<\mathbf{x} \leq \mathbf{4 , 0 0}$ & Very Valid \\
$\mathbf{2 , 5 0} \leq \mathbf{x} \leq \mathbf{3 , 2 5}$ & Valid \\
$\mathbf{1 , 7 5}<\mathbf{x}<\mathbf{2 , 5 0}$ & Less Valid \\
$\mathbf{1 , 0 0}<\mathbf{x}<\mathbf{1 , 7 5}$ & Not Valid \\
\hline
\end{tabular}

Table 2. Instrument Reliability Categories

\begin{tabular}{ll}
\hline Value of Reliability & Category \\
\hline $\mathbf{0 , 8 0} \leq_{\mathbf{1 1}}$ & High reliability \\
$\mathbf{0 , 4} \leq_{\mathrm{r} 11}<\mathbf{0 , 8 0}$ & Medium reliability \\
$\mathbf{r}_{11}<\mathbf{0 , 4}$ & Low reliability \\
\hline
\end{tabular}

\section{RESULT AND DISCUSSION}

\section{Result}

The number of assessments developed was in the form of 12 items with cognitive levels C4, C5, and C6. Each question developed raises issues related to green consumerism. The results of the question development can be seen in tables 3 and 4 . The results of the expert assessment validation and validation using Pearson, and reliability calculations show that all the questions developed are valid and reliable for use in learning. A more detailed explanation of Validity and reliability can be seen in the table below.

After the grid was created, HOTS-based Green Consumerism assessment was developed. The number of assessments developed is 12 questions. All assessments developed have HOTS categories which can be seen in table 4 . Assessment that has been developed then validates the expert. The experts included 7 experts. the results showed that the HOTS assessment developed was valid and appropriate to use. More details can be seen in table 5

Table 3. The assessment grid developed

\begin{tabular}{lll}
\hline Aspect & \multicolumn{1}{c}{ Item } \\
\hline C4 (Analyzing) & $\begin{array}{l}\text { analyze the impact of using too much plastic for the environment and } \\
\text { health }\end{array}$ & 1,2 \\
& $\begin{array}{l}\text { analyze products that are environmentally friendly and that are not } \\
\text { environmentally friendly }\end{array}$ & 3,4 \\
\hline C5 (Evaluating) & evaluate a product in terms of green consumerism & 5,6 \\
\cline { 2 - 3 } & provide a critique of a person's behavior in terms of green consumerism & 7,8 \\
\hline C6 (Creating) & \begin{tabular}{l} 
make hypotheses about an event related to environmental pollution \\
\cline { 2 - 3 }
\end{tabular} & $\begin{array}{l}\text { design an environmentally friendly product/project based on the green } \\
\text { consumerism concept that has been delivered }\end{array}$ \\
\hline
\end{tabular}


Table 4. Assessment Items that have been developed

\begin{tabular}{ll}
\hline No & Item \\
\hline 1 & Stores on the market usually use plastic bags as a tool to carry buyers' groceries. Meanwhile, \\
more plastic waste has caused the river flow to be blocked. However, the use of plastic is still \\
considered necessary, and cannot be replaced. Write an analysis of the impact of using plastic \\
continuously on the environment! \\
The type of plastic that is widely used in addition to plastic bags is Styrofoam. This object is \\
usually used as a snack container in the school canteen. What impact can it have on the use of \\
the Styrofoam for health and the environment? Write an analysis of this problem! \\
If there are 2 pieces of shampoo products, both claim that the product is the best. But only one \\
product is environmentally friendly. As students who understand green consumerism, Write an \\
analysis of the differences between the two products based on green consumerism! \\
The use of mosquito repellent spray, mosquito coils, and topical insect repellent (lotion) have \\
their respective advantages. All three certainly have a different impact on the environment, \\
write your analysis!
\end{tabular}

5 A product has an FSC logo on the packaging, while the other product does not contain the logo on the packaging. Evaluate the quality of the product containing the FSC logo?

6 An electric bicycle can run for 2 hours with time to fully charge the battery for 3 hours. Whereas motorbikes that use BBM only need 10 minutes to fill the fuel. Evaluate and give argumentation, which vehicle is the most suitable for going to a shop that is only $2 \mathrm{~km}$ away from home? Why?

7 Budi is a student in a junior high school. One time he was asked by his teacher because he did not bring a private bottle drink to school, even though it was recommended to bring it. Budi reasoned that he was lazy to take it to school because he only had to buy bottled mineral water in the school canteen. What can you criticize from Budi's behavior? Explain!

8 Adi is a neighborhood leader in his neighborhood. One day he ordered his citizens to clean the waterways in his neighborhood. The residents angrily refused because they felt they had paid the services of a janitor, so there was no need for the community to clean the environment. What can you criticize regarding the policies of neighborhood leader and the response of the citizens! as a good citizen, what should be done?

9 A group of fish was found dead suddenly in a river. Even though the day before, the fish lived well and healthy on the river. The head of the village who came immediately took a sample of the river water and took it to the laboratory for examination. After that, the lab results show that the fish died due to lack of oxygen, but the condition of the fish was found to be durable not like a carcass in general. The day before, someone caught a CCTV camera that drew a large pipe from the tempe and tofu factory into the river. Based on this problem make a hypothesis, about what substance is removed? And why?

10 Plants in the garden initially live fertile. One time the owner of the garden threw acid into the soil with a very large amount. What would happen to the plants in the garden? What hypothesis can you make?

11 Please make a design of an environmentally friendly bag product that can contain many items such as food, vegetables, books etc. Write down from (1) basic materials (2) manufacturing techniques (3) sketch drawings to be made (4) estimated the cost of manufacture (5) advantages and disadvantages!

12 Empty land is not used by the owner. One day the owner gave an offer to anyone who would cooperate using the land. of course, the provisions for profit sharing will be obtained later. As someone who cares about the environment, what project will you design to cultivate the vacant land? So that the land has a positive impact on the environment and produces coffers of money. 
Table 5. The result of expert Validation

\begin{tabular}{lllll}
\hline No & Expert & Score & Average score & Category \\
\hline 1 & User 1 & 3.60 & & \\
2 & User 2 & 3.75 & & \\
3 & User 3 & 3.60 & 3.60 & Very valid \\
4 & User 4 & 3.75 & & \\
5 & User 5 & 3.83 & & \\
6 & User 6 & 3.08 & & \\
7 & User 7 & 3.60 & & \\
\hline
\end{tabular}

After the expert validation assessment was carried out, the next step was to conduct a trial in the class. The results show that the assessment developed for the whole item is valid. In addition, the assessment developed has a moderate reliability category. More details can be seen in tables 6 and 7 .

After testing the validity, HOTS scores of students are taken based on gender. Data analysis using a t-test shows that $\mathrm{t}$ count $<\mathrm{t}$
Table and can be interpreted that accept Ho. This indicates there is no difference in the average HOTS score of male and female students. Further explanation can be seen in the graph and table 8 below.

Graph 1 shows that the average HOTS score of male students is lower than that of female students. Although the score obtained is not very different and significant. This is based on the results of the t-test carried out previously.

Table 6. The result of Validity using Pearson Correlation

\begin{tabular}{llll}
\hline Item & Pearson Correlation $(\mathbf{r x y})$ & r table $(\mathbf{0 . 0 1}$ level) & Category \\
\hline 1 & 0.730 & 0.409 & Valid \\
2 & 0.700 & 0.409 & Valid \\
3 & 0.690 & 0.409 & Valid \\
4 & 0.620 & 0.409 & Valid \\
5 & 0.485 & 0.409 & Valid \\
6 & 0.424 & 0.409 & Valid \\
7 & 0.521 & 0.409 & Valid \\
8 & 0.590 & 0.409 & Valid \\
9 & 0.524 & 0.409 & Valid \\
10 & 0.640 & 0.409 & Valid \\
11 & 0.610 & 0.409 & Valid \\
12 & 0.425 & 0.409 & Valid \\
\hline
\end{tabular}

Table 7. The result of the Reliability Test

\begin{tabular}{lc}
\hline Type of Test & Value $\left(\mathbf{r}_{11}\right)$ \\
\hline Correlation Between Forms & .301 \\
Spearman-Brown Coefficient & .463 \\
Guttmann Split-Half Coefficient & .449 \\
\hline Category & Medium reliability \\
\hline
\end{tabular}


Table 8. t-test results for HOTS students' scores between male and female

\begin{tabular}{cccccc}
\hline F & Sig. & t & df & Sig. & Mean Difference \\
\hline .576 & .450 & -.628 & 108 & .531 & -1.63636 \\
\hline
\end{tabular}

Graph 1. Mean Score of HOTS of Male and Female Students

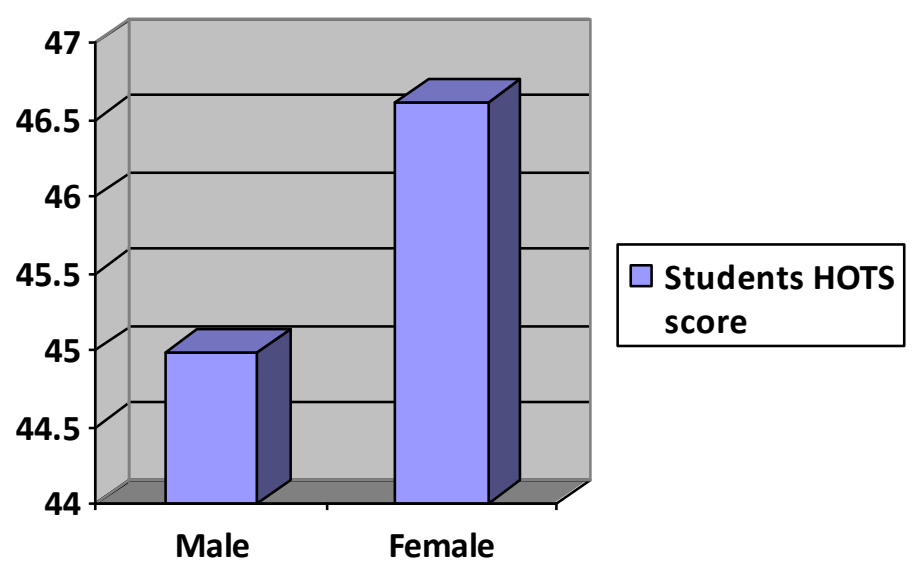

\section{Discussion}

The assessment developed has various advantages according to the experts, namely the words used in accordance with the context of the current problems. Then the HOTS question developed also fits the indicators that have been made. This can be seen from the appearance of the operational verbs of each item. This is important because HOTS must be measured according to its level C4, C5, and C6 (Garcia, 2015; Saido, Siraj, Nordin, \& Amedy, 2015; Sharif \& Cho, 2015).

Furthermore, based on the results of the t-test, it was concluded that the HOTS scores of students obtained by male and female students had no difference. The average HOTS score of all students both male and female is also still relatively low, which is at number 45.79 (rating scale 0-100). This indicates that HOTS students in environmental learning still need to be improved. The low student HOTS can be caused by various things ranging from the learning media used, the assessment used, the learning model, and the learning strategies/methods used (Duran \& Dökme, 2016; Khuana, Khuana, \& Santiboon, 2017; Molenaar, Sleegers, \& van Boxtel, 2014; Mutrofin, Degeng, Ardhana, \& Setyosari, 2017; Suryanda, Azrai, \& Wari,
2016).

The media used in environmental learning should have characteristics that can stimulate the analysis and critical abilities of students. With regard to green consumerism, there are many aspects that can be criticized by students, for example, related to the use of plastic bottles for drinking bottles that must be reduced. This can be given to students then students love to assess and evaluate and criticize the use of plastic for environmental sustainability around them in accordance with aspects of green consumerism about the use of plastic products. Media that can be used by teachers in order to stimulate the growth of analytical power and critical students in the environment, namely learning media based on Android, websites, videos, e-books and many others (Fauzi \& Fariantika, 2018; Fitriani, Adisyahputra, \& Komala, 2018; Ichsan, Dewi, Hermawati, \& Iriani, 2018; Jiang et al., 2017; Kleebbua \& Siriparp, 2016; Reyna, Hanham, \& Meier, 2018). The use of digital-based learning media is highly recommended for use in environmental learning because it will help in delivering learning material (Hidayati \& Wuryandari, 2012; Jiang et al., 2017; Moghavvemi, Sulaiman, Jaafar, \& Kasem, 2018; Suhendar \& Wahyuni, 2018; Yusop \& Sumari, 2013). Learning media that are not available in 
schools can also be developed by teachers and researchers in the field of education. This is to be able to answer the challenges of the 21 st century based on the digital world.

The development of media in environmental learning for the topic of discussion on green consumerism is also deemed necessary because many students have low pro-environmental behavior (Amarasinghe \& Fernando, 2014; Dono, Webb, \& Richardson, 2010; Ertz, Karakas, \& Sarigöllü, 2016; Ichsan, Sigit, \& Miarsyah, 2018). Then the second aspect that can be addressed to improve HOTS is to familiarize students with HOTS-based tests. Teachers must often carry out HOTS-based assessments. This is because in order to familiarize students in recognizing the characteristics of HOTS category questions. The assessment developed can also be an alternative.

This validated assessment can be included in each teacher's lesson planning to be implemented in classroom learning. Learning by using developmental assessment has several advantages such as in accordance with the actual situation, the language used can be adjusted to the characteristics of students, and most importantly can measure something you want to measure in more detail in this case related to the concept of green consumerism in environmental learning. The most important thing in the assessment is that the assessment must be authentic so that the learning outcomes can be truly measurable (Aziz \& Yusoff, 2016; Barber, King, \& Buchanan, 2015; Ichsan, Sigit, Miarsyah, Azrai, \& Heryanti, 2019; Kinay \& Bagceci, 2016; van der Veen \& van Oers, 2017).

Finally, to improve HOTS can also be used models, strategies, and methods that stimulate student creativity. One model that can be used is Project-based learning, this model is very suitable because students will be asked to make a project and this is related to the realm of C6 (creating). Students will be trained to be creative and make things like products (Elif, 2016; Ichsan \& Mulyani, 2018; Ritter \& Mostert, 2017; Yang, Lee, Hong, \& Lin, 2016).

In terms of learning environments, projects or products that can be done by students, for example, use used goods to be made a craft. This is in accordance with the aspect of green consumerism in the aspect of recycling and waste reduction. In addition to project-based learning, this learning can also be applied to problem-based learning that emphasizes the problems students must analyze.
This will increase the realm of $\mathrm{C} 4$ and $\mathrm{C} 5$ in students. Of course, this is very good and positive for students (Barber et al., 2015; Ichsan, Iriani, \& Hermawati, 2018; Istiana \& Awaludin, 2018; Jewpanich \& Piriyasurawong, 2015; Winarno, Muthu, \& Ling, 2017).

Overall the way that can be done to improve HOTS is to make learning more innovative. Interesting learning will make students become more active in environmental learning. This will have a good impact on learning the environment itself, considering that if students are active it will be easier to direct them to the desired direction, namely increasing HOTS (Hamouda \& Tarlochan, 2015; Ito \& Kawazoe, 2015; Sesen \& Tarhan, 2010; Tesfaye \& Berhanu, 2015). Improving HOTS itself cannot be sudden. Various interested parties including parents can apply various lessons to their children at home so they can have high HOTS too.

In green consumerism-based environmental learning like this, we recommend using various existing innovations to improve HOTS. The development of questions carried out in order to indirectly incorporate green consumerism concepts into learning. This is important because green consumerism learning in schools is still low (Chander \& Muthukrishnan, 2015; Kaiser \& Wilson, 2004; Markaki, 2014). This makes the developed assessment very useful for environmental learning. The critique of this assessment is related to the technicality of making questions that are still inserted images in assessment. Overall the questions used are good for use in class.

\section{CONCLUSION AND SUGGESTION}

Based on the results of the study, it can be concluded that HOTS assessment based on $\mathrm{GC}$ is developed valid and reliable so that it can be used in learning. The measurement results of HOTS students in green consumerism-based environmental learning also showed that the average HOTS of students was still low. Advice that can be given is that further research should carry out development to improve the ability of students HOTS by developing teaching materials, worksheets, or learning media.

\section{REFERENCES}

Amarasinghe, S. R., \& Fernando, F. F. H. G. 
(2014). Pro-environmental behavior regarding solid waste management in householders of Kalutara urban council area: A case study. Journal of Tropical Forestry and Environment, 4(1), 80-84.

Anderson, L. W., Krathwohl, D. R., Airiasian, W., Cruikshank, K. A., Mayer, R. E., \& Pintrich, P. R. (2001). A taxonomy for learning, teaching and assessing: $A$ revision of Bloom's Taxonomy of educational outcomes: Complete edition. New York: Longman.

Aziz, M. N. bin abdul, \& Yusoff, N. M. (2016). Improving Process Writing with the Use Authentic Assessment. International Journal of Evaluation and Research in Education, 5(3), 200-204.

Barber, W., King, S., \& Buchanan, S. (2015). Problem based learning and authentic assessment in digital pedagogy: Embracing the role of collaborative communities. Electronic Journal of E-Learning, 13(2), 59-67. https://doi.org/10.1002/tl.7401

Çankaya, I., \& Dag, M. (2017). Comparison of Academic Achievement Levels of Students Beginning the Elementary School at Different Ages. Journal of Education and Practice, 8(3), 140-143. Retrieved from http://ezproxy.lib.uconn.edu/login?url=http s://search.ebscohost.com/login.aspx?direct $=$ true $\& \mathrm{db}=$ eric $\& \mathrm{AN}=\mathrm{EJ} 1131865 \&$ site $=\mathrm{eh}$ ost-live

Chander, P., \& Muthukrishnan, S. (2015). Green consumerism and pollution control. Journal of Economic Behavior and Organization, $\quad 114$, 27-35. https://doi.org/10.1016/j.jebo.2015.02.013

Dono, J., Webb, J., \& Richardson, B. (2010). The relationship between environmental activism, pro-environmental behaviour and social identity. Journal of Environmental Psychology, 30(2), 178-186. https://doi.org/10.1016/j.jenvp.2009.11.00 6

Duran, M., \& Dökme, I. (2016). The effect of the inquiry-based learning approach on student's critical-thinking skills. Eurasia Journal of Mathematics, Science and Technology Education, 12(12), 2887-
2908.

https://doi.org/10.12973/eurasia.2016.0231 1a

Elif, C. O. (2016). Improved creative thinkers in a class: A model of activity based tasks for improving university students creative thinking abilities. Educational Research and Reviews, 11(8), 517-522. https://doi.org/10.5897/ERR2015.2262

Ertz, M., Karakas, F., \& Sarigöllü, E. (2016). Exploring pro-environmental behaviors of consumers: An analysis of contextual factors, attitude, and behaviors. Journal of Business Research, 69(10), 3971-3980. https://doi.org/10.1016/j.jbusres.2016.06.0 10

Fauzi, A., \& Fariantika, A. (2018). Courses perceived difficult by undergraduate students majoring in biology. Biosfer: Jurnal Pendidikan Biologi, 11(2), 78-89. https://doi.org/https://doi.org/10.21009/bio sferjpb.v11n2.78-89

Fitriani, U., Adisyahputra, A., \& Komala, R. (2018). Eco-friendly website development in biology learning based on project activities on environmental pollution. Biosfer: Jurnal Pendidikan Biologi, 11(1), 32-46.

https://doi.org/https://doi.org/10.21009/bio sferjpb.11-1.4

Gall, M. D., Gall, J. P., \& Borg, W. R. (2003). Educational Research An Introduction. San Fransisco: Pearson Education.

Garcia, L. C. (2015). Environmental Science Issues for Higher- Order Thinking Skills (HOTS) Development: A Case Study in the Philippines. In Biology Education and Research in a Changing Planet (pp. 4554). https://doi.org/10.1007/978-981-287524-2

Gu, W., Chhajed, D., Petruzzi, N. C., \& Yalabik, B. (2015). Quality design and environmental implications of green consumerism in remanufacturing. International Journal of Production Economics, 162, 55-69. https://doi.org/10.1016/j.ijpe.2014.12.040

Hamouda, A. M. S., \& Tarlochan, F. (2015). 
Engaging Engineering Students in Active Learning and Critical Thinking through Class Debates. Procedia - Social and Behavioral Sciences, 191, 990-995. https://doi.org/10.1016/j.sbspro.2015.04.37 9

Han, H., \& Yoon, H. J. (2015). Hotel customers' environmentally responsible behavioral intention: Impact of key constructs on decision in green consumerism. International Journal of Hospitality Management, 45, 22-33. https://doi.org/10.1016/j.ijhm.2014.11.004

Hidayati, N., \& Wuryandari, A. I. (2012). Media Design for Learning Indonesian in Junior High School Level. Procedia - Social and Behavioral Sciences, 67, 490-499. https://doi.org/10.1016/j.sbspro.2012.11.35 4

Ichsan, I. Z., Dewi, A. K., Hermawati, F. M., \& Iriani, E. (2018). Pembelajaran IPA dan Lingkungan: Analisis Kebutuhan Media Pembelajaran pada SD, SMP, SMA di Tambun Selatan, Bekasi. JIPVA (Jurnal Pendidikan IPA Veteran), 2(2), 131-140. https://doi.org/10.31331/jipva.v2i2.682

Ichsan, I. Z., Iriani, E., \& Hermawati, F. M. (2018). Peningkatkan Keterampilan Berpikir Tingkat Tinggi (Higher Order Thinking Skills) Pada Siswa Sekolah Dasar Melalui Video Berbasis Kasus Pencemaran Lingkungan. Edubiotik: Jurnal Pendidikan, Biologi Dan Terapan, 3(2), 12-18.

Ichsan, I. Z., \& Mulyani, S. W. W. (2018). Improving Students' Motoric Skills Through Demonstration Method in Recycling Plastic Waste. JPBI (Jurnal Pendidikan Biologi Indonesia), 4(2), 189194.

https://doi.org/10.22219/jpbi.v4i2.5890

Ichsan, I. Z., Sigit, D. V., \& Miarsyah, M. (2018). Learning Environment: Gender Profile of Students' Pro-Environmental Behavior (PEB) based on Green Consumerism. Tadris: Jurnal Keguruan Dan Ilmu Tarbiyah, 3(2), 97-107. https://doi.org/10.24042/tadris.v3i2.3358

Ichsan, I. Z., Sigit, D. V., Miarsyah, M., Azrai,
E. P., \& Heryanti, E. (2019). Students' pro-environmental behavior and environmental learning outcomes based on green consumerism. JPBI (Jurnal Pendidikan Biologi Indonesia), 5(1).

Istiana, R., \& Awaludin, M. T. (2018). Enhancing biology education students ability to solve problems in environmental science material through inquiri modelbased lesson study. Biosfer: Jurnal Pendidikan Biologi, 11(1), 57-66. https://doi.org/https://doi.org/10.21009/bio sferjpb.11-1.6

Ito, H., \& Kawazoe, N. (2015). Active Learning for Creating Innovators: Employability Skills beyond Industrial Needs. International Journal of Higher Education, 4(2), 81-91. https://doi.org/10.5430/ijhe.v4n2p81

Jewpanich, C., \& Piriyasurawong, P. (2015). Project-Based Learning Using Discussion and Lesson-Learned Methods via Social Media Model for Enhancing Problem Solving Skills. International Education Studies, 8(6), 24-31. https://doi.org/10.5539/ies.v8n6p24

Jiang, B., Yang, J., Lv, Z., Tian, K., Meng, Q., \& Yan, Y. (2017). Internet cross-media retrieval based on deep learning. Journal of Visual Communication and Image Representation, 48, 356-366. https://doi.org/10.1016/j.jvcir.2017.02.011

Kaiser, F. G., \& Wilson, M. (2004). Goaldirected conservation behavior: The specific composition of a general performance. Personality and Individual Differences, 36(7), 1531-1544. https://doi.org/10.1016/j.paid.2003.06.003

Khuana, K., Khuana, T., \& Santiboon, T. (2017). An instructional design model with the cultivating research-based learning strategies for fostering teacher students creative thinking abilities. Educational Research and Reviews, 12(15), 712-724. https://doi.org/10.5897/ERR2017.3239

Kinay, I., \& Bagceci, B. (2016). The Investigation of the Effects of Authentic Assessment Approach on Prospective Teachers' Problem-Solving Skills. 
International Education Studies, 9(8), 5159. https://doi.org/10.5539/ies.v9n8p51

Kleebbua, C., \& Siriparp, T. (2016). Effects of Education and Attitude on Essential Learning Outcomes. Procedia - Social and Behavioral Sciences, 217, 941-949. https://doi.org/10.1016/j.sbspro.2016.02.06 1

Lekakos, G., Vlachos, P., \& Koritos, C. (2014). Green is good but is usability better? Consumer reactions to environmental initiatives in e-banking services. Ethics and Information Technology, 16(2), 103117. https://doi.org/10.1007/s10676-0149337-6

Markaki, V. (2014). Environmental Education through Inquiry and Technology. Science Education International, 25(1), 86-92.

Matthes, J., \& Wonneberger, A. (2014). The skeptical green consumer revisited: Testing the relationship between green consumerism and skepticism toward advertising. Journal of Advertising, 43(2), 115-127.

https://doi.org/10.1080/00913367.2013.83 4804

Moghavvemi, S., Sulaiman, A., Jaafar, N. I., \& Kasem, N. (2018). Social media as a complementary learning tool for teaching and learning: The case of youtube. International Journal of Management Education, 16(1), 37-42. https://doi.org/10.1016/j.ijme.2017.12.001

Molenaar, I., Sleegers, P., \& van Boxtel, C. (2014). Metacognitive scaffolding during collaborative learning: a promising combination. Metacognition and Learning, 9(3), 309-332.

Mutrofin, Degeng, N. S., Ardhana, W., \& Setyosari, P. (2017). The Effect of Instructional Methods (Lecture-Discussion versus Group Discussion) and Teaching Talent on Teacher Trainees Student Learning Outcomes. Journal of Education and Practice, 8(9), 203-209. Retrieved from

http://search.ebscohost.com/login.aspx?dir ect $=$ true $\& \mathrm{db}=$ eric $\& A N=$ EJ1138824\&site $=$ ehost-live
Owusu-Agyeman, Y., Larbi-Siaw, O., Brenya, B., \& Anyidoho, A. (2017). An embedded fuzzy analytic hierarchy process for evaluating lecturers' conceptions of teaching and learning. Studies in Educational Evaluation, 55(May), 46-57. https://doi.org/10.1016/j.stueduc.2017.07.0 01

Ratumanan, T. ., \& Laurens, T. (2006). Evaluasi Hasil Belajar yang Relevan dengan Kurikulum Berbasis Kompetensi. Surabaya: Unesa University Press.

Reyna, J., Hanham, J., \& Meier, P. (2018). The Internet explosion, digital media principles and implications to communicate effectively in the digital space. E-Learning and Digital Media, 15(1), 36-52. https://doi.org/10.1177/204275301875436 1

Ritter, S. M., \& Mostert, N. (2017). Enhancement of Creative Thinking Skills Using a Cognitive-Based Creativity Training. Journal of Cognitive Enhancement, 1(3), 243-253. https://doi.org/10.1007/s41465-016-0002-3

Saido, G. M., Siraj, S., Nordin, A. B. Bin, \& Amedy, O. S. A. (2015). Higher Order Thinking Skills Among Secondary School Students in Science Learning. The Malaysian Online Journal of Educational Science, 3(3), 13-20.

Sesen, B. A., \& Tarhan, L. (2010). Promoting active learning in high school chemistry: Learning achievement and attitude. Procedia - Social and Behavioral Sciences, 2(2), 2625-2630. https://doi.org/10.1016/j.sbspro.2010.03.38 4

Sharif, A., \& Cho, S. (2015). 21st-Century Instructional Designers: Bridging the Perceptual Gaps between Identity, Practice, Impact and Professional Development. RUSC. Universities and Knowledge Society Journal, 12(3), 72-85. https://doi.org/10.7238/rusc.v12i3.2176

Suhendar, S., \& Wahyuni, A. (2018). Achievement and response of students at favorite junior high schools in sukabumi on trends in international mathematics and 
science study (timss) questions. Biosfer: Jurnal Pendidikan Biologi, 11(2), 126133.

https://doi.org/https://doi.org/10.21009/bio sferjpb.v11n2.126-133

Suryanda, A., Azrai, E. P., \& Wari, N. (2016). Pengaruh Penerapan Model Pembelajaran Group Investigation (GI) Terhadap Kemampuan Berpikir Analisis Siswa Pada Materi Pencemaran Lingkungan. Biosfer: Jurnal Pendidikan Biologi, 9(2), 37-44. https://doi.org/https://doi.org/10.21009/bio sferjpb.9-2.6

Talmi, I., Hazzan, O., \& Katz, R. (2018). Intrinsic Motivation and 21st-Century Skills in an Undergraduate Engineering Project: The Formula Student Project. Higher Education Studies, 8(4), 46. https://doi.org/10.5539/hes.v8n4p46

Tesfaye, S., \& Berhanu, K. (2015). Improving Students ' Participation in Active Learning Methods : Group Discussions, Presentations And Demonstrations: A Case of Madda Walabu University Second Year Tourism Management Students of 2014. Journal of Education and Practice, 6(22), 29-33.

van der Veen, C., \& van Oers, B. (2017). Advances in research on classroom dialogue: learning outcomes and assessments. Learning and Instruction, 48, $1-4$.

https://doi.org/10.1016/j.learninstruc.2017. 04.002

Vidergor, H. E., \& Krupnik-Gottlieb, M. (2015). High order thinking, problem based and project based learning in blended learning environments. In Applied Practice for Educators of Gifted and Able Learners (pp. 217-232). https://doi.org/10.1007/978-94-6300-0048_11

Vijayaratnam, P. (2012). Developing Higher Order Thinking Skills and Team Commitment via Group Problem Solving: A Bridge to the Real World. Procedia Social and Behavioral Sciences, 66, 53-63. https://doi.org/10.1016/j.sbspro.2012.11.24 7
Wall, T. F. (2015). The Transferability of Higher Order Cognitive Skills. Procedia Social and Behavioral Sciences, 174, 233238. https://doi.org/10.1016/j.sbspro.2015.01.65 2

Weninger, C. (2018). Problematising the notion of "authentic school learning": insights from student perspectives on media/literacy education. Research Papers in Education, 33(2), 239-254. https://doi.org/10.1080/02671522.2017.12 86683

Winarno, S., Muthu, K. S., \& Ling, L. S. (2017). Direct Problem-Based Learning (DPBL): A Framework for Integrating Direct Instruction and Problem-Based Learning Approach. International Education Studies, 11(1), 119-126. https://doi.org/10.5539/ies.v11n1p119

Xia, B. S. (2017). An In-Depth Analysis of Teaching Themes and the Quality of Teaching in Higher Education: Evidence from the Programming Education Environments. International Journal of Teaching and Learning in Higher Education, 29(2), 245-254. Retrieved from http://search.ebscohost.com.proxyub.rug.nl/login.aspx?direct=true $\& \mathrm{db}=$ eric $\& \mathrm{AN}=\mathrm{EJ} 1146146 \&$ site $=$ ehostlive\&scope $=$ site

Yang, K. K., Lee, L., Hong, Z. R., \& Lin, H. S. (2016). Investigation of effective strategies for developing creative science thinking. International Journal of Science Education, 38(13), 2133-2151. https://doi.org/10.1080/09500693.2016.12 30685

Yusop, F. D., \& Sumari, M. (2013). The Use of Social Media Technologies among Malaysian Youth. Procedia - Social and Behavioral Sciences, 103, 1204-1209. https://doi.org/10.1016/j.sbspro.2013.10.44 8 